\title{
1980 Nikaragua Okuryazarlık Kampanyası'ndaki Propaganda Posterlerinin Kitap Okuma Boyutunda İncelenmesi
}

\section{An Examination of the Propaganda Posters in the 1980 Nicaragua Literacy Campaign in the Context of Reading Books}

\author{
Mehmet Ali Gazi*, Caner Çakı*, Mustafa Karaca** ve Gül Çakı***
}

$\ddot{O} z$

1979 yılında Nikaragua'da meydana gelen devrim sonucunda Sandinista Ulusal Kurtuluş Cephesi (Frente Sandinista de Liberación Nacional, FSLN), ülke yönetimini devralmış ve 1980 yılında okuryazarlık kampanyasını başlatmıştır. FSLN'nin kurucusu Carlos Fonseca'nın kütüphaneci ve ögretmen olmasl, kampanyanın ayrl bir önem kazanmasına yol açmıştır. Kampanyada okuryazarlığın ve kitap okumanın önemine vurgu yapılması amacıyla propaganda posterlerinden etkin bir şekilde yararlanılmıştır. Kampanya, 1980 yılında UNESCO Nadezhda K. Krupskaya okuryazarlık ödülüne layık görülmüştür. Çalışmada okuryazarlık kampanyasında okuryazarlı̆̆ın ve kitap okumanın teşvik edilmesi amacıyla propaganda posterlerinden ne şekilde yararlanıldığı ortaya konulmaya çalışılmıştır. Bu amaçla çalışmada Amsterdam'daki Uluslararası Sosyal Tarih Enstitüsü'nden (Internationaal Instituut voor Sociale Geschiedenis) propaganda posterlerine ulaşılmış ve ulaşılan propaganda posterlerindeki görsel ve yazıl göstergeler, ABD'li dilbilimci Charles William Morris'in göstergebilimindeki üç boyutu ışı̆̆ında analiz edilmiştir. Elde edilen bulgularda, propaganda posterleri üzerinden okuryazarlı̆̆ın insanları özgürleştirdiği ileri sürülerek ve okuryazarlık devrimle özdeşleştirilerek insanların okuryazar olmasının ve kitap okumasının teşvik edilmesine çalışıldı̆̆g ortaya çıkarılmıştır.

Anahtar Sözcükler: Kitap; okuma alışkanlığı; okuryazarlık; Nikaragua, propaganda.

\author{
Abstract \\ The Sandinista National Liberation Front (Frente Sandinista de Liberación Nacional, FSLN) \\ took over the administration of the country as a result of the revolution that took place in \\ Nicaragua in 1979 and started a literacy campaign in 1979. The fact that FSLN's founder,

\footnotetext{
${ }^{*}$ Dr. Öğr., Üyesi. Malatya Turgut Özal Üniversitesi Görsel İletişim Tasarımı Bölümü.

E-posta: maligazi@gmail.com

Assist. Prof. Dr., Malatya Turgut Ozal University, Department of Visual Communication Design

** Arş., Gör., İnönü Üniversitesi İletişim Bilimleri ABD.

E-posta: caner.caki@inonu.edu.tr

Res. Assist. Inonu University Department of Communication Sciences

*** Doç., Dr. Anadolu Üniversitesi Siyaset Bilimi ve Kamu Yönetimi ABD.

E-posta:mustafa_karaca@anadolu.edu.tr

Assoc. Dr. Anadolu University Department of Political Science and Public Administration

**** Doktora Öğrencisi, Maltepe Üniversitesi Halkla İlişkiler ve Reklamcılık ABD.

E-posta: gulcaki06@hotmail.com

PhDStudent. Maltepe University Public Relations and Advertising Department
}

Geliş Tarihi - Received: 03.02 .2021

Kabul Tarihi - Accepted: 26.03.2021 
Carlos Fonseca, is a librarian and a teacher, made the campaign gain a special importance. Propaganda posters were used effectively to emphasize the importance of literacy and reading books in the campaign. The campaign was awarded the UNESCO Nadezhda K. Krupskaya literacy award in 1980. It was tried to reveal how propaganda posters were used in literacy campaign in order to encourage literacy and reading books in the study. For this purpose, propaganda posters were accessed from the International Institute of Social History (Internationaal Instituut voor Sociale Geschiedenis) in Amsterdam and visual and written indicators in propaganda posters were analyzed in the light of three dimensions in semiotics of the US linguist Charles William Morris. In the findings obtained, it was revealed that efforts were made to encourage people to be literate and to read books asserting the perception that literacy liberates peopleand identifying literacy with revolution through the propaganda posters.

Keywords: Book; reading habit; literacy; Nicaragua; propaganda.

\section{Giriş}

1979 yılında Nikaragua'da gerçekleşen devrim sonucunda devlet başkanı Anastasio Somoza Debayle devrilmiş ve ülkede 43 yıl boyunca (1936-1979) süren Somoza ailesinin iktidarı son bulmuştur. Devrimden sonra Nikaragua'da yönetime gelen Sandinista Ulusal Kurtuluş Cephesi (Frente Sandinista de Liberación Nacional, FSLN), ülkenin eğitim, sağlık ve sosyal refah alanlarındaki bazı ciddi sorunlarının üstesinden gelmeyi amaçlayan bir dizi reformu uygulamaya koymuştur (Sandiford vd., 1994, s. 35). FSLN, devrimden kısa bir sonra da ülkede okuryazar sayısını arttırabilmek için okuryazarlık kampanyası başlatmıştır. Ulusal Okuryazarlık Haçlı Seferi (Cruzada Nacional de Alfabetización, CNA) olarak adlandırılan kampanya, en başarılı ulusal okuma yazma kampanyalarından biri olmuştur (Bender-Slac, 2018, s. 271). Nikaragua'da okuryazarlığın artmasıyla, insanlar daha geniş ölçüde bilgi kaynaklarına ulaşabilmekte, bu da yeni yönetim tarafından gerçekleştirilen propaganda faaliyetlerinin kitlelere daha kolay ulaşmasını sağlayabilmektedir. Yeni yönetim tarafindan gerçekleştirilen okuryazarlık kampanyası, Nikaragua'nın sosyal devlet olma yönünde önemli bir adımı olarak değerlendirilebilmektedir. Nitekim okuryazarlığın arttırılmasıyla, Nikaragua halkı yüksek öğrenimlerini sürdürme olanağı elde etmekte, bu şekilde istihdam olanakları genişleyebilmektedir.

23 Mart 1980 tarihinde başlatılan okuma yazma kampanyası kapsamında da (Arnove, 1981, s. 245), Nikaragua halkından destek alabilmek için de okuryazarlığı ve kitap okumasını yücelten propaganda faaliyetine girişilmiştir. Bu aşamada kampanyada okuryazarlığın ve kitap okumanın önemini kitlelere benimsetmek amacıyla propaganda posterleri etkili bir şekilde kullanılmıştır. Posterlerde hem görsel hem yazılı mesajlardan kitlelerin okuryazar olması teşvik edilmiştir. Özellikle okuma yazma bilmeyen insanlar, posterdeki görseller üzerinden kampanya kapsamında verilen mesajları anlayabilme olanağı elde etmiştir.

Nikaragua' da gerçekleşen devrimi konu alan pek çok akademik çalışma bulunmaktadır (De La Pena, 1980; Siebert, 1980; Gorman, 1981; Molyneux, 1984; Schaefer-Rodriguez, 1985; Jameson, 1987; Cuzán, 1990; Wright, 1990; Gariazzo, 1991; Prevost, 1996; Ryan, 2000; Zimmermann, 2001; Pérez, 2002; Rocha, 2003; Sáez, 2007; Palazón Sáez, 2008; Azuaje, 2010; Bataillon ve Juárez, 2013; Guerrero, 2014; Booth, 2019; Mosinger, 2019). Bu çalışmalar 
1980 Nikaragua Okuryazarlık Kampanyası'ndaki Propaganda Posterlerinin Kitap Okuma Boyutunda İncelenmesi

içerisinde: Marini (1981), devrim ve Orta Amerika devrim sürecini; Cuzán ve Heggen (1982), devrimin mikro-politik açıklamasını; Downs ve Kusnetzoff (1982), devrimde yerel yönetimin değişen rolünü; Coraggio (1984), Serra Vázquez (1985), Ortega (1989), devrim ve demokrasiyi; Gordon (1985), devrim ve etnik yapıy1; Fisher (1986), devrimi ve ABD tepkisini; Hodges (1986), devrimin entelektüel temellerini; Rooper ve Smith (1986), devrimde etnik sorunu; Vilas (1990), devrimin geleceğini; Quintanilla (1993), devrim ve görsel sanatlar1; Vargas (1998), devrim ve restorasyonu; De Diego Romero (2003), devrim ve siyasi meşruiyeti; Smith (2008)devrim ve siyaseti; Perla (2009), devrimi ve ABD-Nikaragua dayanışma hareketini; González Arana (2010) devrimi ve diktatörlüğü; Krujit (2011), devrim ve karşı devrimi; Gordon ve Munro (1983) devrim ve uluslararası örgütleri incelemiştir.

Nikaragua'da devrimi inceleyen çalışmaların dışında Nikaragua'da eğitimi konu alan çeşitli akademik çalışmalar da bulunmaktadır (Jamison vd. 1981; Collins, 1987; Arnove, 1995a; Peña vd., 2000; Hernández vd. 2008; Martinez-Rugama vd., 2017). Bu çalışmalar içerisinde de: Bloch ve Acevedo (1988), kütüphane eğitimini; Gurdián ve Salamanca (1990) iki dilli eğitimi; Arnove ve Dewees (1991) eğitim ve devrimci dönüşümü; Torres (1991) Nikaragua'da resmi olmayan eğitim ve sosyalizmi; Arnove (1995b), yetişkin eğitimini; Frost (1995), yerli çocukların iki dilli eğitimini; Miron (1995), özel eğitimin gelişimini; Peña vd. (1999), kadın eğitimini; Garfield ve Vermund (1986), Kroeger vd. (1996), Steppe vd. (2020),sağlık eğitimini; Gershberg (1999), eğitimin özerkleştirilmesini; Polvorosa (2002) eğitim sisteminin zorluklarını; Müller (2007), eğitim ve cinsiyeti; Handa vd., (2009), kalkınma önceliği olarak yaygın temel eğitimi; Geale (2010), anne eğitimini; Catter (2011), kültürlerarası eğitimi; Mora (2013), beş yıllık yerli eğitimi; Shier vd. (2013), eğitim hakkını; Martínez ve Arrechavala (2020), küreselleşme ve eğitimi incelemiştir.

Çalışmanın konusu olan Nikaragua okuma yazma kampanyasını inceleyen alana ilişkin olarak çok sayıda akademik çalışmanın bulunduğu da ortaya çıkmaktadır (Angus, 1980; Cardenal Martínez, 1980; Tünnermann Bernheim, 1980; Arnove, 1981; Cordero ve Monge, 1981; Deiner, 1981; Armas, 1984; MacAdam, 1984; Kleinbach, 1985; Rodríguez, 1990; Sandiford vd., 1994; Jiménez, 1998; Baracco, 2004; Hanemann, 2006; Vannini, 2007; Parra, 2008; Terradellas ve Parra, 2008; Bender-Slack, 2018; Miller, 2019; Bender-Slack, 2020). Bu çalışmalarda da: Torres (1980), Cardenal ve Miller, (1982), devrim ve okuryazarlığı; Flora vd. (1983), Nikaragua okuma yazma kampanyasının siyasi bilinç üzerindeki etkisini; Lankshear (1986), Nikaragua'da okuma yazma hakkını; Lankshear vd. (1995), kadın okuryazarlığını; Fernandez (1985) Nikaragua'da okuryazarlık ve yetişkin eğitimini; Robles ve Lucio-Villegas (2014), okuryazarlık ve katılımı ele almıştır.

Son yıllarda Türkiye'de kütüphanecilik, kitap okuma alışkanlığı ve okuryazarlık konularında afişlerin ve posterlerin incelendiği çeşitli akademik çalışmalar yapılmaktadır. $\mathrm{Bu}$ çalışmalar içerisinde: Aladağ (2019), Fransız dilbilimci Roland Barthes'ın göstergebilim metodu üzerinden Türkiye'deki "Kütüphane Haftası” afişlerini incelemiştir. Çalışmada afişler üzerinden verilmek istenen mesajlar, düz anlam, yan anlam, metafor ve metonimi boyutunda kapsamlı olarak ele alınmıştır. 
Gazi vd. (2020) de Barthes'ın göstergebilim kavramları üzerinden Çin Kültür Devrimi'nde (1966-1976) okuma alışkanlığının şekillenmesinde posterlerin rolünü analiz etmiştir. Elde edilen bulgularda posterler üzerinden Çin halkının kültürel bir mücadele içerisinde olduğuna yönelik algı oluşturulduğu ve Mao'yu ve devrimi yücelten yayınlarla da bu mücadeleden üstün gelinebileceğine vurgu yapıldığı sonucuna ulaşılmıştır.

Çakı vd. (2020), Rus dilbilimci Roman Jakobson'un göstergebilim kavramları üzerinden Rusya'da Vladimir Lenin döneminde başlatılan veLikbez adıyla bilinen okuryazarlık kampanyasında kullanılan posterleri incelemiştir. Çalışma sonucunda posterlerde kitap okumanın, Komünizm ideolojisiyle yakınlaşmanın bir yolu olarak sunulduğuna ulaşılmıştır.

Nikaragua'daki okuryazarlık kampanyası, bugüne kadar gerçekleştirilen okuryazarlık kampanyaları içerisinde en dikkat çeken kampanyalardan biri olmuş ve yukarıda da ele alındığı üzere konuya ilişkin farklı açılardan çok sayıda akademik çalışma gerçekleştirilmiştir. $\mathrm{Bu}$ çalışmada ise Nikaragua' daki okuryazarlık kampanyasında posterler üzerinden gerçekleştirilen propagandaya 1şık tutulması amaçlanmıştır. Bu amaçla çalışmada Nikaragua'da okuryazarlık kampanyası sürecinde kullanılan propaganda posterleri göstergebilim yöntemi kullanılarak incelenmiştir. İncelenen propaganda posterlerinde okuryazarlık ve kitap okuma boyutunda hangi söylemlere yer verildiği, hangi konuların ön plana çıkarıldığ 1 ve kitapların ne şekilde sunulduğu ortaya konulmaya çalışılmıştır. Böylece çalışmada "Nikaragua' daki okuryazarlık kampanyasında okuryazarlığın ve kitap okumanın teşvik edilmesinde propaganda posterleri ne şekilde kullanılmıştır?" sorusuna yanıt verilmesi amaçlanmıştır. Çalışmada elde edilen bulgular, Nikaragua'da okuryazarlık kampanyasındaki propagandayı açıklaması, Nikaragua'nın yakın tarihi hakkında bilgi vermesi ve okuryazarlık kampanyasında posterlerin kullanımına 1şık tutması bakımından önem taşımaktadır.

Çalışma kapsamında Nikaragua'da gerçekleştirilen okuma kampanyasında kullanılan posterler ele alınarak Nikaragua halkının hangi görsel ve yazılı mesajlar üzerinden okuryazar olmasının ve kitap okumasının teşvik edildiği ortaya konulabilmektedir. Bu şekilde posterler üzerinden kampanyanın içeriği ve gerçekleştirilen okuryazarlık propagandasının kapsamı hakkında bilgi verilebilmektedir. Diğer yandan çalışma, devrim sonrasında yeni yönetimin Nikaragua halkı için okuryazarlığa ne kadar önem verdiğini de yansıtmaktadır. Çalışmada okuryazarlıkla birlikte Nikaragua toplumunda bilgiye ulaşım konusunda ne gibi değişimlerin yaşandığı açıklanmaya çalışılmıştır. Bu şekilde yeni yönetimin okuryazarlık kampanyasıyla ideolojik söylemlerine mi yoksa doğrudan bilginin önemine mi vurgu yaptığının ortaya konulması hedeflenmiştir. Diğer bir deyişle okuryazarlık kampanyasında insanların okuryazar olduktan sonra hangi kitapları okumaları gerektiği yönünde bir yönlendirmede bulunup bulunulmadığı da çalışmada incelenmiştir.

\section{Nikaragua Devrimi ve FSLN'nin Nikaragua'da İktidara Gelişi}

19 Temmuz 1961 tarihinde kütüphaneci ve aynı zamanda öğretmen olan Carlos Fonseca tarafindan Sandinista Ulusal Kurtuluş Cephesi (Frente Sandinista de Liberación Nacional, FSLN) adlı siyasi bir parti kurulmuştur. Parti, zaman içerisinde çeşitli guruplardan aldığ desteklerle 1936 yılından 1979 yılına kadar kırk üç yıl boyunca Nikaragua'da otokratik bir aile yönetimi olarak hüküm süren Somoza ailesine karşı önemli bir siyasi güç haline gelmiştir. FSLN'nin elde ettiği güç zaman içerisinde Somoza ailesinin ülkede etkinliğini kaybetmesine 
1980 Nikaragua Okuryazarlık Kampanyası'ndaki Propaganda Posterlerinin Kitap Okuma Boyutunda İncelenmesi

yol açmıştır. FSLN, 1979 yılı içerisinde başkent Managua dışında ülkede kontrol kurmayı başarmıştır. Rejimi kurtarmak için yabancı askeri müdahaleyi sağlayamayan devlet başkanı Anastasio Somoza Debayle de ülkeyi terk etmiştir (Gorman, 1981, s. 137). Somoza'nın ülkeyi terk etmesinden sonraki süreçte FSLN yönetime gelmeyi başarmıştır. Somoza'nın düşüşü, nüfusun geniş bir kesitinin siyasi faaliyete dahil edilmesiyle karakterize edilen, büyüyen bir halk muhalefetinin sonucu olmuştur (Molyneux, 1984, s. 179). Devrimin zaferi, Latin Amerika'da Küba Devrimi tarafından açılan toplumsal mücadeleler döngüsünde yeni bir aşamanın bir dereceye kadar sonucunu ve aynı zamanda başlangıcını temsil etmiştir (Marini, 1981, s. 62). Somoza'nın devrilmesinden sonra Ulusal Yeniden Yapılanma Cuntası (Junta de Gobierno de Reconstrucción Nacional) kurulmuş ve başkanlığına FSLN'den Daniel Ortega seçilmiştir. Devrim, Somoza'yı devirmekle birlikte (Nolff, 1982, s. 33), ülkede tam bir istikrar ortamın sağlanmasını mümkün kılamamıştır. Nitekim Contras (Kontralar) olarak da bilinen Contrarevolucionarios (karşı devrimciler), FSLN'in karşıtı bir hareket olarak ortaya çıkmıştır. Kontralar, FSLN'ye karşı mücadelede eden ve 1990'ların başına kadar aktif olan isyancı gruplar olmuştur. Kontralar içerisinde de Nikaragua Demokratik Gücü (Fuerza Democrática Nicaragüense, FDN) ön plana çıkmıştır. FSLN ülke içerisinde Kontralar'ın muhalefetine maruz kalırken aynı zamanda uluslararası alanda ABD'yle de karşı karşıya kalmıştır. 1981 yııında ABD başkanı Ronald Reagan'ın göreve başlamasından sonra ABD ve Nikaragua arasındaki ilişkiler, Somoza iktidarı döneminin aksine olumsuz bir seyre dönmüş ve Reagan, FSLN'ye karşıtı bir politikaya yönelmiştir. Tüm bu yaşananlar Nikaragua'da istikrarın sağlanmasını oldukça zorlaştırmıştır. Buna karşılık FSLN, ABD'nin onu iktidardan çıkarma çabalarına direnmiş (Perla, 2009, s. 80) ve Kontralar'a karşı mücadeleyi sürdürmüştür. Ayrıca FSLN, ülkede olağanüstü hâl ilan etmiş ve olağanüstü hâl durumu uzun bir dönem devam etmiştir.

Nikaragua'da devriminden sonra 4 Kasım 1984 tarihinde genel seçim gerçekleştirilmiştir. Seçimde FSLN oyların \%66,78'sini alarak önemli bir seçim başarısı elde etmiş̧tir. Ortega da \%66,97 oy oranı elde ederek devlet başkanı seçilmiştir. Buna karşılık 25 Şubat 1990 tarihinde gerçekleşen seçimde Ulusal Muhalefet Birliği (Unión Nacional Opositora, UNO) oyların $\% 53,9$ 'unu alarak birinci parti olurken, FSLN ise $\% 40,8$ oy oranı ile ikinci parti olmuştur. Diğer yandan Ortega seçimde Violeta Chamorro'ya yenilerek (Anderson, 1992, s. 93) devlet başkanlığından ayrılmıştır.

\section{Nikaragua Okuryazarlık Kampanyasına Genel Bakış}

İnsanlar, okuryazar olduklarında sosyo-ekonomik açıdan pek çok avantaj elde edebilmektedir. Bir ülkede okuryazarlığın arttırılması, insanların iyi bir eğitim almasına imkân sağlamakta ve bu şekilde ülkede çok sayıda eğitim almış kalifiye elamanların istihdamı da sağlanabilmektedir. Diğer yandan okuryazar nüfusun artmasıyla yönetimler, söylemlerini ve ideolojilerini kitlelere daha kolay benimsetme imkânı bulabilmektedir. Bu nedenle pek çok ülkede okuryazar nüfusun arttırılmasına yönelik çalışmalar yapılmıştır. Çalışmalar kapsamında kimi zaman halkın seferber edildiği okuryazarlık kampanyaları gerçekleştirilmiştir. 1980 yılında Nikaragua'da gerçekleştirilen okuryazarlık kampanyası da bu kampanyalardan biridir. 
1979 y1lında meydana gelen Nikaragua Devrimi'nden önce Nikaragua'da nüfusun önemli bir bölümü okuryazar değildi. Devrim ise okuryazar olmama sorununun çözülmesinde önemli bir süreci başlatmıştır. Okuryazar olmama sorununun üstesinden gelme projesi, devrimci mücadelenin başlangıcından beri mevcut olmuştur. Bu nedenle devrimden sonra FSLN, ülkedeki okuryazarlığın arttırılmasını sağlamak için harekete geçmiştir. Diğer yandan ülkenin istikrarsız ekonomik durumu göz önüne alındığında da kampanyanın ancak halk kitlelerinin örgütlenmesi ve seferber edilmesiyle gerçekleştirilmesi söz konusu olmuştur (Fernandez, 1985, s. 133). FSLN, okuryazarlı̆̆ın ülke genelinde arttırılması için 23 Mart 1980 tarihinde Nikaragua' da okuryazarlık kampanyası başlatmıştır. Ulusal Okuryazarlık Haçlı Seferi (Cruzada Nacional de Alfabetización) adiyla bilinen kampanya, Somoza ailesinin devrilmesinden kısa bir süre sonra gerçekleştirilmiştir. Kampanya, 23 Ağustos 1980 tarihine kadar sürmüş ve kampanyada ülkenin dört bir yanından gelen gönüllüler yer almıştır. Kampanya kapsamında insanların gönüllü olmasını teşvik etmek için de çalışmalar yapılmıştır. Nüfus sayımı verilerine göre 10 yaş üstü toplam nüfusun \%50'sinin okuma yazma bilmediği ortaya konulmuştur. Kırsal kesimde de 10-14 yaş grubunun \%74-80'inin de okuma yazma bilmediği sonucuna ulaşılmıştır. Nüfus sayımı ayrıca her üç okuma yazma bilmeyen kişi için öğretmenlik yapacak bir kişinin mevcudiyetini ortaya çıkarmıştır. Kampanya kapsamında nüfus sayımı sonuçlarına göre ülke iki bölgeye ayrılmıştır. Kentsel bölgelerde, kampanyanın temel organizasyonu Sandinista Savunma Komiteleri'ne (Comites de Defensa Sandinista, CDS) bırakılırken, kırsal bölgelerde Tarımsal Kalkınma Bakanlığı, Eğitim Bakanlığı, 19 Temmuz Sandinista Gençliği (La Juventud Sandinista 19 de Julio, JS), Çiftlik İşçileri Derneği (Asociación de Trabajadores del Campo, ATC) ve Nikaragua Ulusal Eğitimciler Derneği’nden (Asociación Nacional de Educadores de Nicaragua, ANDEN) destek gelmiştir. Kent-kır ayrımı iki büyük Nikaragua okuma yazma öğretmeni grubunun oluşmasına yol açmıştır: Halk Okuryazarlığı Öğretmenleri (Los Alfabetizadores Populares, AP) ve Halk Okuryazarlı̆̆1 Ordusu (El Ejército Popular de Alfabetización, EPA). AP gönüllüleri boş zamanlarında kentsel alanlarda okuma yazma öğretmiştir. Gönüllü öğretmenler ve orta öğretim ve üniversite öğrencilerinden oluşan EPA da tam zamanlı çalışmak için birkaç aylığına kırsal ve dağlık bölgelere gitmiştir (Deiner, 1981, s. 120). Mücadele imgesi, kelime dağarcığ 1 ve ulusal bir savaş, kampanyanın sembolleştirilmesinde büyük bir yer tutmuştur. EPA'nın altı ulusal cephesi, çoğu okuma yazma bilmeyen köylülerle çalışmak, öğrenmek ve öğretmek için ülkenin kırsal bölgelerinde yaşayan yaklaşık 65.000 tugadistadan (okuma yazma işçileri) oluşmuştur (Arnove, 1981, s. 248).

Okuryazarlık olgusunun politik doğasından, okumayı, yazmayı ve hesaplamayı öğrenmenin kampanyanın tek ya da en önemli amacı olmadığı ortaya çıkmaktadır. Kampanya kapsamında kitlelerin devrimci sürece dahil edilmesi ve köylülüğün yaşam koşullarının iyileştirilmesi de önemli bir adım olmaktadır. Bu açıdan okuma yazma bilmemenin ortadan kaldırılmasına ek olarak, kampanya kapsamında başka amaçlar da yer almaktadır. Örneğin, insanların kendi tarihlerine, değerlerine ve yaşadıkları devrimci sürece sahip çıktıkları bir farkındalık süreci geliştimek bu amaçlardan biri olmaktadır. Ayrıca işçiler ve köylülerle doğrudan temas yoluyla gençlerin bilinçlenmesi, böylece birliğin güçlendirilmesi de amaçlanmıştır. Çevre sağlı̆̆ı, hijyen ve koruyucu hekimlik konularında eğitim çalışmaları yürütmek ve şiirler, şarkılar ve halkın mücadelelerinin tarihini toplayan kayıtlar ve arkeolojik 
alanların tespiti yoluyla kültürün ve tarihin canlandırılması da amaçlardan bazılarını oluşturmuştur (Fernandez, 1985, s. 133-134). Yoksul ve okuma yazma bilmeyen nüfusa okuma ve yazma öğretmek için ülkenin kırsal bölgelerine 60 binden fazla genç seferber olmuştur. Beş ay süren kampanya sayesinde okuryazar bilmeyenlerin oranı $\% 50,3$ 'ten $\% 2,9$ 'a düşmüștür. Katılımcı ve destekleyici doğası nedeniyle kampanya, Nikaragua tarihindeki en önemli eğitim ve kültür etkinliğinden biri haline gelmiştir (Vannini, 2007, s. 118). 1981 yılında Nikaragua, kampanyanın başarısı nedeniyle UNESCO'nun Nadeshda Krupskaya ödülüne layık görülmüştür (Sandiford vd., 1994, s. 36). Diğer yandan kampanya, Nikaragua'da devriminin ilk aşamalarında meydana gelen dönüşümleri diğer olay veya süreçlerden daha çok sembolize etmiş̧tir. Nitekim, devrimden sonraki ilk yıl olan 1980 yılı, Eğitim Y1lı ilan edilmiştir (Arnove, 1987, s. 269-270).

\section{Metodoloji}

Çalışma kapsamında Nikaragua Okuryazarlık Kampanyası'nı konu alan propaganda posterlerine Hollanda Kraliyet Bilim ve Sanat Akademisi bünyesindeki Uluslararası Sosyal Tarih Enstitüsü (Internationaal Instituut voor Sociale Geschiedenis, IISG) üzerinden erişilmiştir. Çalışmada IISG'de konuya ilişkin toplam 29 propaganda posterine ulaşılmıştır. Çalışma kapsamında ulaşılabilen tüm posterler 29 tane olduğu için çalışma bu posterler üzerinden incelenmiştir. Ulaşılan propaganda posterlerinin içerik ve konu bakımından birbirine benzer olması nedeniyle verilmek istenen propaganda mesajlarını en iyi şekilde yansıtacağı düşünülen 9 propaganda posteri çalışmanın örneklemi olarak belirlenmiştir. Çalışmada örneklem olarak belirlenen 9 propaganda posteri, göstergebilim yöntemi kullanılarak analiz edilmiştir.

Göstergebilim alanında çeşitli uzmanların kavram ve modelleri bulunmaktadır (Çakı vd., 2017, s. 73; Gülada, 2019 s. 223; Erol, 2020, s. 703). Bu çalı̧̧mada ise propaganda posterlerindeki görsel ve yazılı göstergeler, ABD'li dilbilimci Charles William Morris'in göstergebilimdeki üçboyutu (sözdizimsel, anlambilimsel, edimbilimsel) 1şığında incelenmiş̧ir. Sözdizimsel boyut, belirli anlamların oluşturulabilmesi için göstergelerin ne şekilde bir araya getirildiğini ele almaktadır. Anlambilimsel boyut da adında da anlaşılacağı üzere göstergeler yoluyla oluşturulan anlamı açıklamaktadır. Göstergeler üzerinden ortaya konulan anlamlar kültürden kültüre farklılık taşıyabilmektedir. Bu aşamada göstergelerin anlamlarının kapsamlı bir şekilde ele alınabilmesi için göstergelerin kullanıldığı kültürün göstergelere atfettiği anlamların doğru şekilde bilinmesi önem taşımaktadır. Edimbilimsel boyutta ise göstergeler üzerinden ortaya konulmak istenen değişim ifade edilmektedir. Yani göstergelerin bir araya getirilmesiyle oluşan anlamlandırmaların ne gibi bir amacı bulunduğu açıklanmaktadır (Gülada, 2019, s. 335).

Çalışmada belirlenen propaganda posterleri Morris'in göstergebilimdeki üç boyutunun dışında metafor ve metonimi kavramları üzerinden de incelenmiştir. Metafor bir kavramın başka bir kavram yerine eğreti olarak kullanılmasıdır. Bu şekilde kavram, diğer kavramı temsil etmektedir. Metonimi ise aralarında benzerlik bulunan bir kavramın diğeri yerine kullanılmasıdır (Guiraud, 2016, s. 146). Metonimi, bir kavramın tümü temsil etmesini de ifade 
etmektedir. Diğer bir deyişle bir şeyin bir parçası veya onu temsil edecek bir olgunun ön plana çıkarılması da metonimiyi tanımlamaktadır.

\section{Bulgular ve Yorum}

Çalışmanın bu kısmında zincir, özgürlük, kitleler, yumruk, destek, savaş, okuryazar, kadın ve görev konulu 9 propaganda posteri göstergebilimsel açıdan analiz edilmiştir.

\section{“Zincir" Konulu Propaganda Posteri}

Zincir konulu propaganda posteri, sözdizimsel boyut üzerinden incelendiğinde posterde yeşil bir fonda Nikaragua haritasının ve haritanın üstünde de yeşil kaplı bir kitabın resmedildiği görülmektedir. Yeşil kaplı kitabın üzerinde alfabetización es liberación (okuryazarlık özgürlüktür) yazısı bulunmaktadır. Nikaragua haritası zincirle çevrilmiş, kitabın olduğu yerde ise zincir kırılmıştır.

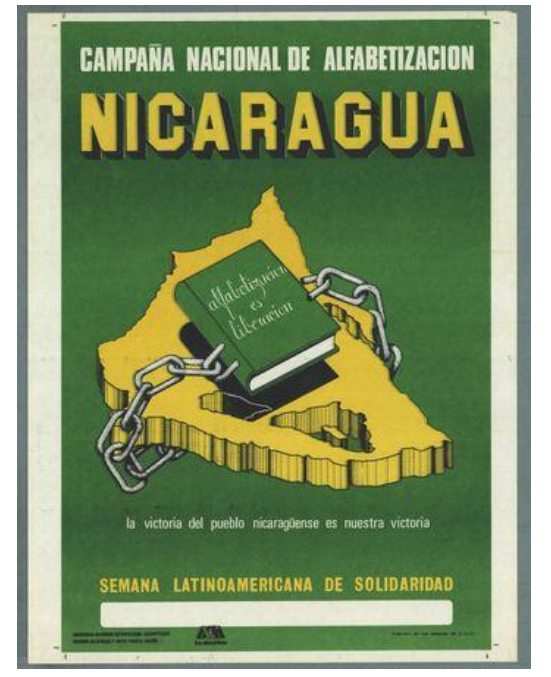

Poster 1.“Zincir” Konulu Propaganda Posteri ${ }^{1}$ (Kaynak: IISG, 2021a).

Posterde yer alan zincir, esaret metaforu olarak kullanılmaktadır. Nikaragua haritası da Nikaragua halkını simgelemektedir. Kitap ise okuryazarlık ve kitap okumayı temsil etmektedir. Kitabın Nikaragua haritası üzerindeki zinciri kırmasıyla Nikaragua halkının okuryazarlık ve kitap okumayla esaretten kurtulacağı mesajı verilmektedir. Bu açıdan anlambilimsel boyut açısından ele alındığında posterde kitabın insanları esaretten kurtardığı algısı meydana getirilmektedir. Nikaragua halkının okuryazar olmadan ve kitap okumadan esaretten kurtulamayacağına yönelik düşünce oluşturulmaktadır. Bu nedenle de edimbilimsel boyut üzerinden incelendiğinde posterde insanların esaretten kurtulması için kitap okumas1 gerektiğine yönelik mesaj verilmektedir. Diğer yandan yazılı kodlar içerisinden okuryazarlığın ve kitap okumanın bir zafer olarak sunulması okuryazarlığın ve kitap okumanın Nikaragua halkı için önemine vurgu yapmaktadır. Posterde yeni yönetimin, insanların okuryazar olmasıyla birlikte bilgiye ulaşmasını teşvik ettiği mesajı ortaya çıkmaktadır. Bu aşamada devrimin temellerinden birinin insanların kitaplar üzerinden bilgiye erişimini sağlamak olduğu belirtilebilmektedir.

\footnotetext{
${ }^{1}$ Posterin üstünde Campaña nacional de alfabetización Nicaragua (Ulusal okuryazarlık kampanyası Nikaragua), altında da La victoria de pueblo nicaragüense es nuestra Victoria (Nikaragua halkının zaferi bizim zaferimizdir) ve Semana Latinoamericana de solidaridad (Latin Amerika dayanışma haftası) yazıları bulunmaktadır.
} 
1980 Nikaragua Okuryazarlık Kampanyası'ndaki Propaganda Posterlerinin Kitap Okuma Boyutunda İncelenmesi

An Examination of the propaganda Posters in the 1980 Nicaragua Literacy Campaing in the Context Of

Reading Books

Tablo 1

“Zincir” Konulu Propaganda Posteri

\begin{tabular}{cc}
\hline Sözdizimsel Boyut & Zincirle çevrili Nikaragua haritası ve kitap \\
Anlambilimsel Boyut & Kitabın insanları esaretten kurtarması \\
Edimbilimsel Boyut & İnsanların esaretten kurtulması için kitap okuması gerektiği \\
\hline
\end{tabular}

\section{“Ö̈gü̈rlük” Konulu Propaganda Posteri}

Özgürlük konulu propaganda posteri, sözdizimsel boyut açısından ele alındığında posterde Nikaragua haritasının üzerinde ellerinde pankartlar ve kitaplar olan insanların resmedildiği görülmektedir. Ön planda bulunan insanların sol ellerini yumruk yaparak havaya kaldırdıkları resmedilmektedir. Posterde yer alan kişiler üstünde Alfabetización es liberacion (Okuryazarlık özgürlüktür) yazan büyük bir pankart taşımaktadır.

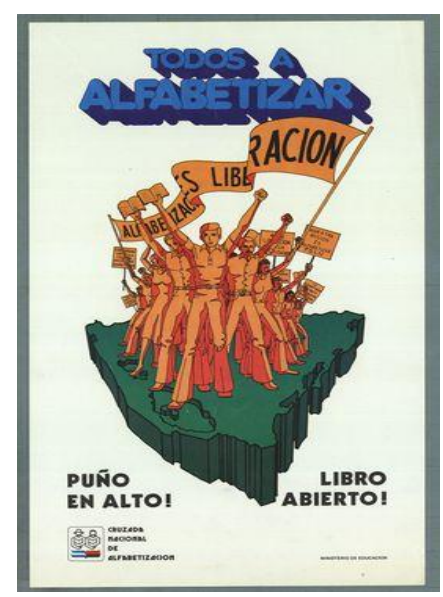

Poster 2. “Özgürlük” Konulu Propaganda Posteri² (Kaynak: IISG, 2021b).

Posterde Nikaragua haritası da Nikaragua halkını simgelemektedir. Haritanın üzerinde yer alan insanlar ise Nikaragua halkının metonimi olarak ön plana çıkarılmaktadır. Kitap ise okuryazarlık ve kitap okumayı temsil etmektedir. Nikaragualıların pankartta yer alan yazıyı taşımaları, Nikaragualıların okuryazarlığın ve kitap okumanın özgürlük sağladığı düşüncesini destekledikleri mesajını vermektedir. Anlambilimsel boyut üzerinden incelendiğinde posterde kitabın insanları özgürleştirdiği algısı meydana getirilmektedir. Bir elle yumruk yapılması, diğer elle de kitabın havaya kaldırılmasıyla okuryazarlık ve kitap okumanın da devrimin bir parçasıymış gibi düşünülmesine yol açılmaktadır. Sonuç olarak edimbilimsel boyut açısından ele alındığında posterde insanların özgürleşmesi için kitap okuması gerektiğine yönelik mesaj verildiği ortaya çıkmaktadır. Posterde haritanın üzerindeki insanlarla da Nikaragua halkının

\footnotetext{
${ }^{2}$ Posterin üstünde Todos a alfabetizar (Herkes okur yazar), sol altında Puño en alto! Libro abierto!(Yumruk havada! Kitap açık!), sağ altında da Cruzada Nacional de Alfabetización (Ulusal Okuryazarlık Kampanyası) yazıları bulunmaktadır.
} 
okuryazarlık ve kitap okumaya destek verdiği algısı oluşturulmaya çalışılmaktadır. Poster üzerinden Nikaragua'daki yeni yönetimin okuryazarlık kampanyası üzerinden Nikaragualıların bilgiye ulaşmasını teşvik ettiği sonucuna ulaşılmaktadır.

\section{Tablo 2}

\section{“Özgürlük” Konulu Propaganda Posteri}

\begin{tabular}{cc}
\hline Sözdizimsel Boyut & Nikaragua haritası üzerindeki insanlar ve kitaplar \\
\hline Anlambilimsel Boyut & Kitabın insanları özgürleştirmesi \\
\hline Edimbilimsel Boyut & İnsanların özgürleşmesi için kitap okuması gerektiği \\
\hline
\end{tabular}

\section{“Kitleler” Konulu Propaganda Posteri}

Kitleler konulu propaganda posteri, sözdizimsel boyut üzerinden incelendiğinde posterde kitaplar taşıyan iki kadın ve iki erkeğin resmedildiği görülmektedir. Erkeklerden biri hasır şapka takmakta, kadınlardan biri de sepet taşımaktadır. Posterin altında ise pankartlar taşıyan bir insan topluluğu yer almaktadır. Pankartlarda ANDEN (Asociación Nacional de Educadores de Nicaragua / Nikaragua Ulusal Eğitimciler Derneği), CST (la Central Sandinista de Trabajadores, Sandinista İşçilerin Merkezi), ATC (Asociación de Trabajadores del Campo / Çiftlik İşçileri Derneği), CDS (Los Comites de Defensa Sandinistas / Sandinista Savunma Komiteleri), AMNLAE (La Asociacion de Mujeres 'Luisa Amanda Espinoza' / 'Luisa Amanda Espinoza' Kadınlar Derneği) ve La Juventud Sandinista 19 de Julio (19 Temmuz Sandinista Gençliği) yazıları bulunmaktadır.

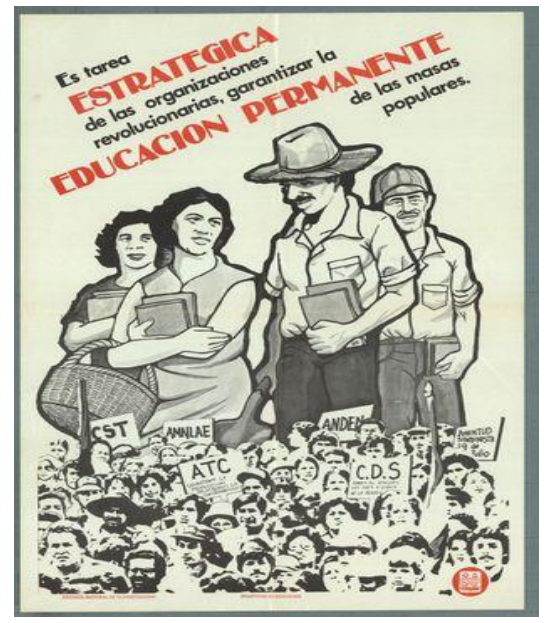

Poster 3. "Kitleler" Konulu Propaganda Posteri³ (Kaynak: IISG, 2021c).

Posterde taşınan pankartlardaki yazılardan posterdeki insanların Nikaragualılar olduğu anlaşılmaktadır. Diğer yandan posterde ön plana çıkarılan iki erkekten birinin başında yer alan hasır şapka, Nikaragualıların metonimi olarak kullanılmaktadır. Nitekim hasır şapka,

\footnotetext{
${ }^{3}$ Posterin üstünde Es tarea estrategica de las organizaciones revolucionarias, garantizar la educacion permanente de las masas populares (Halk kitlelerinin kalıcı eğitimini garanti altına almak devrimci örgütlerin stratejik görevidir) yazısı bulunmaktadır.
} 
Nikaragualıların geleneksel olarak giydikleri bir şapkadır. Bir kişinin hasır şapka giymesi kuşkusuz onun doğrudan Nikaragualı olduğunu göstermemektedir. Buna karşılık bir göstergenin tek başına değil bulunduğu göstergelerle bir arada değerlendirilmesi gerekmektedir. $\mathrm{Bu}$ aşamada sözdizimsel boyutta göstergelerin konumlandırılmasından, posterde yer alan kişinin hasır şapkasından bu kişinin Nikaragualı olduğu algısı oluşabilmektedir. Bu açıdan posterde yer alan insanlar ise Nikaragua halkının metonimi olarak ön plana çıkarılmaktadır. Kitap ise okuryazarlık, eğitim ve kitap okumayı temsil etmektedir. Anlambilimsel boyut açısından ele alındığında posterde kitap okumanın devrimin bir parçası gibi sunulduğuna yönelik alg1 meydana gelebilmektedir. Diğer yandan posterde çeşitli pankartlar taşıyan insanlar üzerinden okuryazarlığın ve kitap okumanın Nikaragua'da önemli bir destek bulduğuna yönelik düşünce oluşabilmektedir. Edimbilimsel boyut üzerinden incelendiğinde de posterde Nikaragua halkının kitap okuması gerektiğine yönelik mesaj verildiği ortaya çıkmaktadır. Okuryazarlığın ve kitap okumanın devrimin bir parçası olarak sunulması, Nikaragua'da okuryazarlığa ve kitap okumaya önem atfedilmesine yol açmaktadır. Posterde yeni yönetimin devrimle birlikte insanların yalnızca okuryazar olmasını değil aynı zamanda eğitim almalarını da sağlamayı amaçladığı ortaya çıkmaktadır. Okuryazarlığın, Nikaragua halkının eğitim sürecinin ilk aşaması olduğunun poster üzerinden sunulduğu belirtilebilmektedir. Nitekim Nikaragua halkının, okuryazar olması durumunda yüksek eğitim olanağı elde etmesi söz konusu olabilmektedir.

\section{Tablo 3}

“Kitleler” Konulu Propaganda Posteri

\begin{tabular}{cc}
\hline Sözdizimsel Boyut & Kitap ve pankart taşıyan insanlar \\
\hline Anlambilimsel Boyut & Kitap okumanın devrimin bir parçası olarak sunulması \\
\hline Edimbilimsel Boyut & Nikaragua halkının kitap okuması gerektiği \\
\hline
\end{tabular}

\section{“Yumruk” Konulu Propaganda Posteri}

Yumruk konulu propaganda posteri, sözdizimsel boyut açısından ele alındığında posterde siyah fonda bir erkek ve kırmızı fonda da bir kadın siluetine yer verildiği görülmektedir. Erkek görseli, hasır şapkayı andıran bir şapka takmaktadır. Erkek ve kadın siluetlerinin sol ellerinde kitap tuttuğu ve sağ ellerini yumruk yapıp, yukarı kaldırdıkları resmedilmektedir. Posterin solunda da Nikaragua bayrağının renkleri bulunmaktadır. 


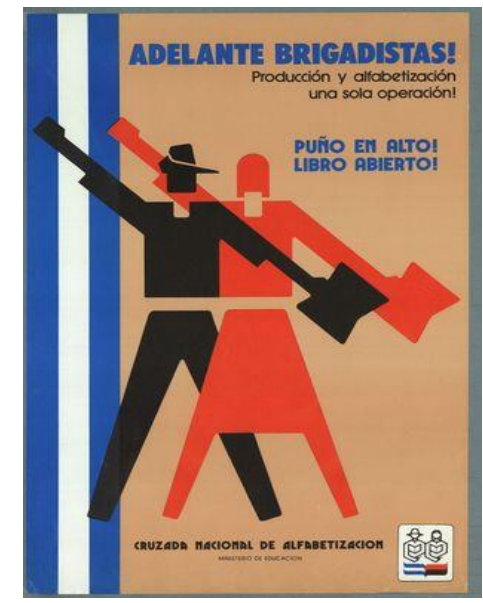

Poster 4. "Yumruk" Konulu Propaganda Posteri ${ }^{4}$ (Kaynak: IISG, 2021d).

Yumruk, devrimin bir simgesi olarak sunulmaktadır. Kitap ise okuryazarlık ve kitap okumayı temsil etmektedir. Nikaragua bayrăğ, Nikaragua halkını simgelemektedir. Çalışma kapsamında incelenen bir önceki posterde olduğu gibi hasır şapka, Nikaraguaların metonimi olarak kullanılmaktadır. Bu açıdan posterde yer alan erkek ve kadın siluetleri, doğrudan Nikaragualıları temsil etmektedir. Anlambilimsel boyut üzerinden incelendiğinde posterde devrim ve kitap okumanın özdeşleştirildiği algısı meydana getirilmektedir. Nikaragua halkının okuryazar olarak ve kitap okuyarak devrim gerçekleştirdiklerine yönelik düşünce oluşabilmektedir. Bu aşamada edimbilimsel boyut açısından ele alındığında posterde insanların kitap okumasının teşvik edilmeye çalışıldığı ortaya çıkmaktadır. Okuryazarlığın ve kitap okumanın devrimle özdeşleştirilmesi, Nikaragualıların okuryazar olması ve kitap okumasının önemine vurgu yapmaktadır. Poster üzerinden Nikaragua halkının okuryazar olmasıyla bilgiye ulaşmasının teşvik edildiğine yönelik algı meydana gelmektedir.

\section{Tablo 4}

"Yumruk" Konulu Propaganda Posteri

Sözdizimsel Boyut Kitap ve pankart taşıyan insanlar

Anlambilimsel Boyut

Edimbilimsel Boyut
Kitap okumanın devrimin bir parçası olarak sunulması

Nikaragua halkının kitap okuması gerektiği

\section{“Destek” Konulu Propaganda Posteri}

Destek konulu propaganda posteri, sözdizimsel boyut üzerinden incelendiğinde posterde bir taburenin üzerinde oturan hasır şapka giyen bir erkeğin resmedildiği görülmektedir. Posterde yer alan erkeğin yanında bir dünya temsili bulunmaktadır. Erkek, sol koluyla dünya temsiline yaslanırken bir taraftan da önündeki üstünde “a, b, c” harfleri bulunan kitaba bakmaktadır.

\footnotetext{
${ }^{4}$ Posterin üstünde Adelante brigadistas! (ileri tugaylar!), Producción y alfabetización una sola operación! (Üretim ve okuryazarlık tek bir iş!), Puño en alto! (Yumruk havada!) ve Libro abierto! (Kitap açık!), altında da Cruzada Nacional de Alfabetización (Ulusal Okuryazarlık Kampanyası) ve Ministerio de Educacion (Eğitim Bakanlığı) yazıları bulunmaktadır.
} 


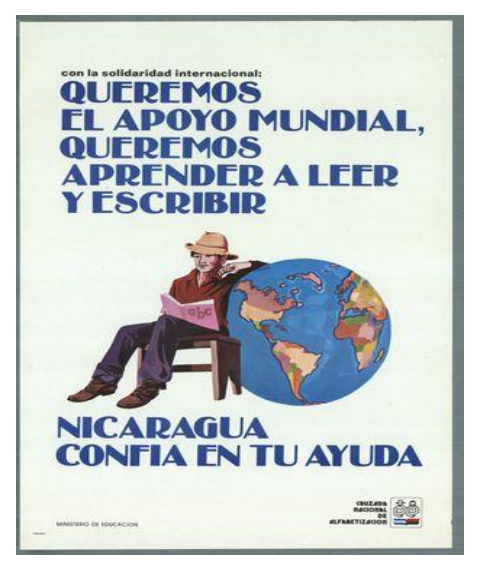

Poster 5. Destek Konulu Propaganda Posteri ${ }^{5}$ (Kaynak: IISG, 2021e).

Posterde bulunan hasır şapka yine Nikaragualıların metonimi olarak kullanılmaktır. $\mathrm{Bu}$ açıdan posterdeki erkek görseliyle doğrudan Nikaragualılar temsil edilmektedir. Posterdeki yazılı kodlardan dünya temsilinin, Nikaragua'ya yapılması istenen yardıma yönelik kullanıldığı anlaşılmaktadır. Posterdeki kitabın üstünde “a, b, c” harflerinin bulunmasıyla kitabın okumayazma öğreten bir kitap olduğu yansıtılmaktadır. Anlambilimsel boyut açısından ele alındığında posterde Nikaragua halkının kitap okumak istediği algısının meydana getirildiği ortaya çıkmaktadır. Edimbilimsel boyut üzerinden incelendiğinde de posterde kitap konusunda dünya çapında destek istendiğineyönelik mesaj verildiği anlaşılmaktadır. Poster üzerinden Nikaragualıların okuryazarlık ve kitap okumaya önem verdiklerine yönelik algı oluşturulmakta, bu şekilde okuryazarlık ve kitap okumayı teşvik eden kampanyanın kitleler nezdinde meşrulaştırılmasına çalışılmaktadır.

Tablo 5

“Destek” Konulu Propaganda Posteri

Sözdizimsel Boyut

Anlambilimsel Boyut

Edimbilimsel Boyut
Dünya temsilinin yanında kitap okuyan adam

Nikaragua halkının kitap okumak istediği

Kitap konusunda destek istenmesi

\section{"Savaş" Konulu Propaganda Posteri}

Savaş konulu propaganda posteri, sözdizimsel boyut açısından ele alındığında posterin üst ve alt olmak üzere iki bölümden oluştuğu görülmektedir. Posterin üstünde evler bulunmakta ve evlerin bulunduğu alanda da barikat kurmuş, çatışma halindeki insanlar resmedilmektedir. Posterin altında ise saman çatılı evlerin önünde oturmakta olan bir gurup insan yer almaktadır.

\footnotetext{
${ }^{5}$ Posterin üstünde Con la solidaridad internacional: (Uluslararası dayanışmayla:) Queremos el apoyo mundial, queremos aprender a leer y escribir (Dünya çapında destek istiyoruz, okumayı ve yazmayı öğrenmek istiyoruz), altında da Nicaragua confia en tu ayuda (Nikaragua yardımınıza güveniyor) veMinisterio de Educacion (Eğitim Bakanlığı) yazıları bulunmaktadır.
} 
Oturmakta olan insanların elinde kitap (ya da defter) bulunmaktadır. Posterin arka planında da bir yanardağ yer almaktadır.

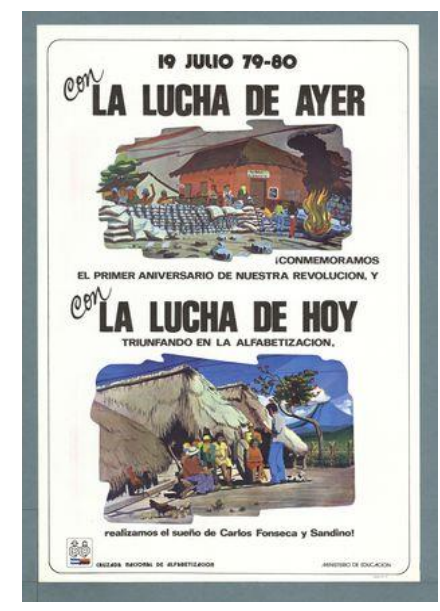

Poster 6. "Savaş” Konulu Propaganda Posteri ${ }^{6}$ (Kaynak: IISG, 2021f).

Posterin üstünde yer alan görsellerde, 1979 y1lında Nikaragua'da gerçekleşen devrime atıf yapıldığı anlaşılmaktadır. Posterin altında yer alan görsellerden ise Nikaragua'daki okuryazarlık çalışmasına vurgu yapıldığı ortaya çıkmaktadır. Yazılı kodlardan posterdeki insanların Nikaragualıların metonimi olarak kullanıldığı anlaşılmaktadır. Anlambilimsel boyut üzerinden incelendiğinde posterde Nikaragua'nın günümüzdeki mücadelesinin okuryazarlık olduğu algısı meydana getirilmektedir. Posterde Nikaragua halkının geçmişteki mücadelesinin silahlı mücadele olduğu aktarılmakta, günümüzde ise mücadelenin eğitim alanında okumayazma seferberliğiyle meydana geldiğine vurgu yapılmaktadır. Edimbilimsel boyut açısından ele alındığında posterde insanların kitap okumasının teşvik edildiği ortaya çıkmaktadır. Posterde Nikaragua halkı için okuryazarlık ve kitap okumanın, 1979 yılında gerçekleşen devrim gibi önem atfettiğine yönelik düşünce oluşmaktadır. Bu şekilde poster üzerinden Nikaragualıların okuryazarlık ve kitap okumanın önemini kavramasına çalışıldı̆̆ ileri sürülebilmektedir. Nikaragua'daki yeni yönetimin, insanların okuryazar olmasıyla birlikte bilgiye ulaşmasını bir mücadele gibi posterde sunduğu belirtilebilmektedir.

\footnotetext{
${ }^{6}$ Posterin üstündeki görselin çevresinde 19 Julio 79-80 (19 Temmuz 79-80), Con la lucha de ayer (dünün savaşıyla), ;Conmemoramos el primer aniversario de nuestra revolucion, y (Devrimimizin birinci yıl dönümünü anıyoruz ve), altındaki görselin çevresinde ise con la lucha de hoy (bugünün savaşıyla), Triunfando en la al alfabetización (Okuryazarlıkta başarılı olmak), Realizamos el sueño de Carlos Fonseca y Sandiono!(Carlos Fonseca ve Sandino'nun hayalini gerçekleştiriyoruz!) yazıları bulunmaktadır.
} 
1980 Nikaragua Okuryazarlık Kampanyası'ndaki Propaganda Posterlerinin Kitap Okuma Boyutunda İncelenmesi

An Examination of the propaganda Posters in the 1980 Nicaragua Literacy Campaing in the Context Of

Reading Books

Tablo 6

“Savaş” Konulu Propaganda Posteri

\begin{tabular}{cc}
\hline Sözdizimsel Boyut & Çatışma halindeki insanlar ve kitap okuyan insanlar \\
Anlambilimsel Boyut & Nikaragua'nın günümüzdeki mücadelesinin \\
okuryazarlık olduğu
\end{tabular}

\section{“Okuryazar” Konulu Propaganda Posteri}

Okuryazar konulu propaganda posteri, sözdizimsel boyut üzerinden incelendiğinde posterde Nikaragualı gerilla önderi Augusto César Sandino'nun (1895-1934) ve Sandinista Ulusal Kurtuluş Cephesi'nin (Frente Sandinista de Liberación Nacional, FSLN) kurucusu, Nikaragualı öğretmen ve kütüphaneci Carlos Fonseca'nın (1936-1976) resimlerinin bulunduğu görülmektedir. Sandino ve Fonseca'nın resimlerinin altında, büyük bir kitabın üstünde yer alan insanlar resmedilmektedir. Kitabın üstündeki insanların ellerinde kitaplar bulunmakta ve bazıları hasır şapka takmaktadır.

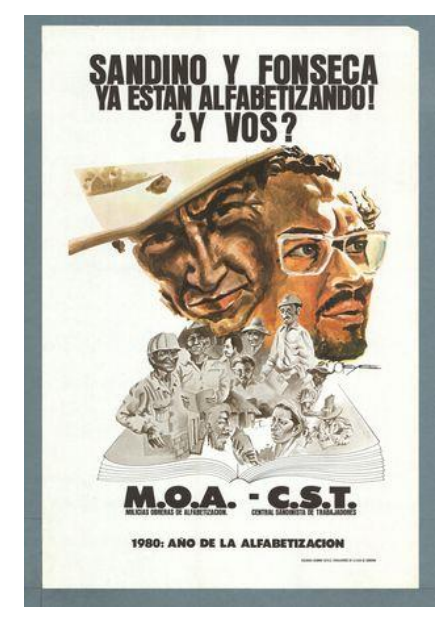

Poster 7. "Okuryazar" Konulu Propaganda Posteri ${ }^{7}$ (Kaynak: IISG, 2021g).

Posterdeki görsel ve yazılı kodlardan büyük kitabın üzerinde yer alan insanların Nikaragualılar olduğu anlaşılmaktadır. Bu aşamada posterdeki insanlar, Nikaragualıların metonimi olarak kullanılmaktadır. Kitap ise okuryazarlık ve kitap okumayı temsil etmektedir. Posterde Sandino ve Fonseca'nın resimleri diğer kişilere nazaran büyük gösterilerek vurgu yapılmaktadır. Anlambilimsel boyut açısından ele alındığında posterde insanların Sandino ve Fonseca gibi okuryazar olmasının gerektiğine yönelik alg1 oluşturulmaya çalışıldığı ortaya çıkmaktadır. Edimbilimsel boyut açısından ele alındığında da posterde Sandino ve Fonseca'ya atıfta

\footnotetext{
${ }^{7}$ Posterin üstünde Sandino y Fonseca ya estan alfabetizando! ¿Y vos?(Sandino ve Fonseca zaten okuryazar! Ya siz?), altında da Milicias Obreras de la alfabetización M.O.A. (Okuryazarlık İşçileri Milisleri M.O.A) - La Central Sandinista de Trabajadores C.S.T. (Sandinista İşçilerin Merkezi C.S.T.), 1980: Año de la alfabetizacion (1980: Okur yazarlık yılı) yazıları bulunmaktadır.
} 
bulunularak insanların kitap okumasının teşvik edilmeye çalışıldığı anlaşılmaktadır. Bu aşamada poster üzerinden Nikaragualıların, Sandino ve Fonseca gibi okuryazar olması ve kitap okumasının amaçlandığı ileri sürülebilmektedir.

\section{Tablo 7}

“Okuryazar” Konulu Propaganda Posteri

\begin{tabular}{cc}
\hline Sözdizimsel Boyut & Sandino, Fonseca, büyük bir kitap ve kitap taşıyan insanlar \\
Anlambilimsel Boyut & İnsanların Sandino ve Fonseca gibi okuryazar olması gerektiği \\
\hline Edimbilimsel Boyut & İnsanların kitap okumasının teşvik edilmesi \\
\hline
\end{tabular}

\section{“Kadın” Konulu Propaganda Posteri}

Kadın konulu propaganda posteri, sözdizimsel boyut açısından ele alındığında posterde kırmızı fonda yerde oturan sekiz kadının resmedildiği görülmektedir. Kadınların dörderli iki gurup olarak oturduğu ve her guruptaki kadının diğer gruptaki bir kadınla yüz yüze olduğu resmedilmektedir. Ön planda yer alan iki kadın kitap okumaktadır. Kadınların ortasında büyük bir çiçek bulunmaktadır. Arka planda da parlayan güneş ve bir dağ resmedilmektedir.

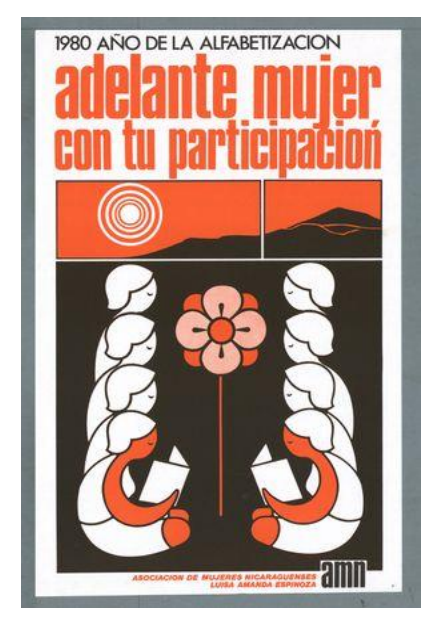

Poster 8. "Kadın” KonuluPropaganda Poster $^{8}$ (Kaynak: IISG, 2021h).

Posterdeki yazılı kodlardan posterdeki kadın görsellerinin Nikaragualı kadınların metonimi olarak kullanıldığı anlaşılmaktadır. Posterdeki çiçek de mutluluk metaforu olarak ön plana çıkarılmaktadır. Kitap ise okuryazarlık ve kitap okumayı temsil etmektedir. Anlambilimsel boyut üzerinden incelendiğinde posterde kadınların okuryazar olması gerektiği algısının meydana getirilmeye çalışıldığı ortaya çıkmaktadır. Bu aşamada kadınların kitap okuması ve önlerinde çiçek bulunması, okuryazar olmanın ve kitap okumanın kadınların hayatını olumlu yönde etkileyeceğine yönelik düşüncenin oluşmasına yol açmaktadır. Edimbilimsel boyut açısından ele alındığında da posterde kadınların kitap okumasının teşvik edilmeye çalışıldığı

\footnotetext{
${ }^{8}$ Posterin üstünde 1980 Año de la alfabetizacion (1980 Okuryazarlık yılı) ve Adelante mujer con tu participación (Kadın, katılımla ilerle), altında da Asociación de Mujeres Nicaragüenses Luisa Amanda Espinoza (Nikaragua Kadınlar Derneği Luisa Amanda Espinoza) yazıları bulunmaktadır.
} 
1980 Nikaragua Okuryazarlık Kampanyası'ndaki Propaganda Posterlerinin Kitap Okuma Boyutunda İncelenmesi

ortaya çıkmaktadır. Bu aşamada kadınların okuryazar olması ve kitap okumasına yönelik olumlu bir algı inşa edilmeye çalışılmaktadır.

\section{Tablo 8}

“Kadın”Konulu Propaganda Posteri

Sözdizimsel Boyut Kitap okuyan kadınlar ve büyük bir çiçek

Anlambilimsel Boyut Kadınların okuryazar olması gerektiği

Edimbilimsel Boyut

Kadınların kitap okumasının teşvik edilmesi

\section{“Görev” Konulu Propaganda Posteri}

Görev konulu propaganda posteri, sözdizimsel boyut üzerinden incelendiğinde posterde saman çatılı evlerin önünde bulunan dört kadının resmedildiği görülmektedir. Ön planda olan kadın elindeki kitabı göstermekte, yanında çapa ve balta bulunan bir diğer kadın da kitaba bakmaktadır. Diğer iki kadının ise işleriyle meşgul oldukları resmedilmektedir. Kitabı gösteren ve kitaba bakan kadınlar, hasır şapkalar giymektedir. Posterin arka planında da bir yanardağ bulunmaktadır.

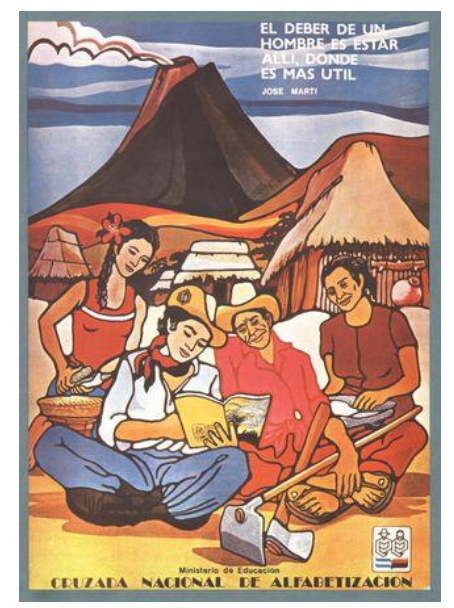

Poster 9. "Görev" Konulu Propaganda Posteri" (Kaynak: IISG, 2021i).

Posterdeki saman çatılı evler, Nikaragua'nın ve hasır şapkalar ise Nikaragualıların metonimi olarak kullanılmaktadır. Posterin arka planında yer alan yanardağ görseli de posterdeki yerin Nikaragua olduğu algısını oluşturmaktadır. Nitekim Nikaragua' da çok sayıda yanardağ bulunmakta ve beş yanardă̆ görseli de Nikaragua bayrağında yer almaktadır. $\mathrm{Bu}$ açıdan yanardağ görseli, Nikaragua'nın bir simgesi olarak ön plana çıkmaktadır. Kitap ise okuryazarlık ve kitap okumayı temsil etmektedir. Anlambilimsel boyut açısından ele alındığında posterde kadınların okuryazar olması gerektiğine yönelik algının oluşturulmaya

\footnotetext{
${ }^{9}$ Posterin sağ üstünde El deber de un hombre es estar alli, donde es mas util. Jose Marti (Bir insanın görevi, en yararlı olduğu yerde olmaktır. Jose Marti), altında da Ministerio de Educacion (Eğitim Bakanlığı) ve Cruzada Nacional de Alfabetización (Ulusal Okuryazarlık Kampanyası) yazıları bulunmaktadır.
} 
çalışıldığı ortaya çıkmaktadır. Kitaba bakan kadınlardan birinin yanında çapa ve baltanın bulunması, kadının çalışma dışındaki zamanında okuma-yazma öğrendiği veya kitap okuduğuna yönelik düşüncenin oluşmasına yol açmaktadır. Bu şekilde Nikaragualıların okumayazmaya ve kitap okumaya istekli olduğu algısı oluşmaktadır. Edimbilimsel boyut açısından ele alındığında posterde kadınların kitap okumasının teşvik edilmeye çalışıldığı ortaya çıkmaktadır. Bu aşamada da kadınların çalışma hayatlarının dışında okuma-yazma öğrenmeye ve kitap okumaya zaman ayırmasına çalışıldığ i ileri sürülebilmektedir. Nikaragua'daki yeni yönetimin, kadınların kitap okumasını teşvik etmesiyle kadınları bilgiyi araştıran ve sorgulayan bireyler olarak idealize ettiği belirtilebilmektedir.

\section{Tablo 9}

\section{“Görev”Konulu Propaganda Posteri}

\begin{tabular}{lc}
\hline Sözdizimsel Boyut & Çalışan ve kitap okuyan kadınlar \\
\hline Anlambilimsel Boyut & Kadınların okuryazar olması gerektiği \\
\hline Edimbilimsel Boyut & Kadınların kitap okumasının teşvik edilmesi \\
\hline
\end{tabular}

\section{Sonuç}

Çalışmada incelenen posterlerde çeşitli algılar oluşturularak Nikaragua'da okuryazarlığın ve kitap okumanın teşvik edilmeye çalışıldığı ortaya çıkmaktadır. Nikaragua'da 1979 yılında gerçekleşen devrimin bir parçası olarak okuryazarlığın sunulması, bunlardan ilkidir. Bu şekilde Nikaragualıların okuma-yazma öğrenmeleriyle ülkede devrimin pekişmesine katk1 sağlayacaklarına yönelik alg1 oluşturulmaya çalışılmıştır. Diğer yandan posterlerde okuryazarlığın benimsetilmesi devrimcilerin bir sorumluluğuymuş gibi sunulmuş ve bu şekilde devrime bağlı olan kişilerin Nikaragua halkının okuryazar olmasına katkı sağlaması gerektiği mesajı verilmiştir. Posterler üzerinden okuryazarlığa büyük önem atfedilmiş, 1980 yılında başlatılan okuryazarlık kampanyasındaki mücadeleyle 1979 yılında gerçekleşen devrim sırasındaki mücadele birbirine benzetilmiştir. Böylece Nikaragua'da okuryazarlık konusunun, Somoza ailesinin iktidardan uzaklaştırılması ve yönetimin FSLN'nin denetimine geçmesi kadar önemli bir konu olduğuna yönelik kamuoyunda algı meydana getirilmeye çalışılmıştır.

Posterlerdeki görsel ve yazılı kodlar üzerinden okuryazarlığın ve kitap okumanın Nikaragua'yı özgürleştirdiğine yönelik algı oluşturulmaya çalışılmıştır. Bu aşamada posterlerde kitaplar, okuryazarlığın simgesi olarak ön plana çıkarılmış ve insanların okuryazar olması ve kitap okumasıyla esaretten kurtulacağı mesajı verilmiştir. Buna karşılık posterlerde esaretin boyutu ya da esaretin kim veya kimler tarafından oluşturulduğuna yönelik herhangi bir bilgi verilmemiştir. Diğer yandan posterlerde 1979 yılında yönetimin ele geçirilmesi suretiyle gerçekleşen devrimin, 1980 yılında okuryazarlık kampanyasıyla sürdürüldüğüne yönelik kamuoyunda algı oluşturulmaya çalışılmıştır. Posterlerde Nikaragua halkının okuryazar olmayı ve kitap okumayı istediğine yönelik alg1 oluşturulmaya çalışıldığ 1 da ortaya çıkmıştır. Bu aşamada posterlerde resmedilen insan görselleri, Nikaragua halkının metonimi olarak kullanılmıştır. Bu şekilde kampanya kapsamında Nikaragua halkının okuryazar olmasının ve 
kitap okumasının, yönetimdeki iktidar tarafından baskıyla gerçekleşmediğine yönelik algı oluşturulmaya çalışılmıştır. Bu açıdan posterler üzerinden okuryazarlık ve kitap okumanın, Nikaragualıların kendi istekleri olduğu mesajı verilerek, okuryazarlık kampanyasının kitleler nezdinde meşrulaştırılmasına çalışıldığı ileri sürülebilmektedir.

Çalışma kapsamında incelenen posterler genel olarak ele alındığında okuryazarlığa ve kitap okumaya yönelik inşa edilen algılar üzerinden posterlerin etkili bir şekilde kullanıldığı sonucuna ulaşılabilmektedir. Özellikle posterlerde okuryazarlığın devrimle özdeşleştirilmesi ve devrimin başarılı bir şekilde sürdürülebilmesi için okuryazar olunmasının bir şart gibi algılatılması, propaganda mesajının kitleler üzerinde daha etkili olmasını sağladığı ileri sürülebilmektedir. Diğer yandan posterlerde okuryazarlık kampanyasının geniş kitleler tarafından desteklendiğine yönelik algı oluşturulması da kampanyanın kitleler üzerinde daha güçlü bir etki meydana getirmesini sağlayabileceği belirtilebilmektedir.

Posterler üzerinden elde edilen bulgular boyutunda değerlendirildiğinde Nikaragua'da devrimden sonra gelen yönetimin, okuryazarlığı Nikaragua halkının bir önceliği olarak sunduğu ortaya çıkmaktadır. Nikaragua halkının bilgiye ulaşması teşvik edilmekte bunun için de okuryazar olması istenmektedir. Kampanya kapsamında Nikaragua halkının okuryazar olarak bilgi düzeyini geliştirebileceğine yönelik mesaj verilmektedir. Posterler yoluyla Nikaragua halkı nezdinde okuryazarlık ve bilgi arasında güçlü bir ilişkinin olduğu algısı meydana getirilmekte, bu şekilde Nikaragua halkının okuryazar olması teşvik edilmeye çalışılmaktadır. Nikaragua yönetimi, okuryazarlık kampanyasında hazırlanan posterler üzerinden Nikaragualıları, bilgiye ulaşmak için mücadele veren ve kitaplar üzerinden bilgisini geliştiren bireyler olarak idealize etmektedir. Tüm bu süreçte posterler, devrimle birlikte toplumsal dönüşümde Nikaragua'daki yeni yönetimin bilgi boyutunda ne gibi söylemlere sahip olduğunu yansıtmaktadır. Çalışmada incelenen posterlerde okuryazarlık kampanyasında yeni yönetimin ideolojik söylemlerini ön plana çıkarmadan doğrudan bilgiye ulaşımın önemine vurgu yapmaya çalıştığı ileri sürülebilmektedir.

Dönemin şartlarında değerlendirildiği Nikaragua'da posterlerin okuryazarlığın ve kitap okumanın teşvik edilmesinde propaganda amaçlı kullanılmasının önemli bir rolü olduğu belirtilebilmektedir. Posterlerde yer alan görseller, okuryazar olmayan Nikaragualıların okuryazarlık ve kitap okumaya yönelik mesajları anlaması sağlayabilmekte, diğer yandan neden okuryazar olmaları gerektiği sorusuna çeşitli açılardan cevaplar verebilmektedir. Posterler, Nikaragua'da muhtelif yerlere asılarak Nikaragualıların doğrudan okuryazarlık ve kitap okuma propagandasına maruz kalmasını sağlayabilmektedir.

Çalışmada elde edilen bulgular, Nikaragua' daki okuryazarlık kampanyasına ışık tutması bakımından önem taşımaktadır. Gelecek çalışmalarda farklı ülkelerin okuryazarlık kampanyalarında kitle iletişim araçlarının okuryazarlık ve kitap okumanın teşvik edilmesindeki rolü incelenebilir. Gerçekleştirilecek bu tür çalışmalarda, mevcut çalışmada elde edilen bulgular üzerinden mesaj stratejisi bakımından karşılaştırmalarda bulunulabilir. 


\section{Kaynakça}

Aladağ, H. (2019). 1960’lar sonrası kütüphanecilik tarihimiz içinde bazı “Kütüphane Haftası” afişlerinin Roland Barthes'in göstergebilim metodu çerçevesinde analizi. Uluslararası Sosyal ve Eğitim Bilimleri Dergisi, 6(12), 133-147. Erişim adresi https://doi.org/10.20860/ijoses.601210

Anderson, L. (1992). Surprises and secrets: Lessons from the 1990 Nicaraguan election. Studies in Comparative International Development, 27(3), 93-119.

Angus, E. (1980). The awakening of a people: Nicaragua's Literacy Campaign. Two Thirds, 2(3), 6-32.

Armas, L. (1984). La alfabetización en Nicaragua. Revista Nueva Sociedad, 52, 85-102.

Arnove, R. F. (1981). The Nicaraguan National Literacy Crusade of 1980. Comparative Education Review, 25(2), 244-260.

Arnove, R. F. (1987). The 1980 Nicaraguan National Literacy Crusade. Arnove, R. F. ve Graff, H. J. (Ed.). National literacy campaigns içinde (s. 269-292). Boston: Springer.

Arnove, R. F., ve Dewees, A. (1991). Education and revolutionary transformation in Nicaragua, 19791990. Comparative Education Review, 35(1), 92-109.

Arnove, R. F. (1995a). Education as contested terrain in Nicaragua. Comparative Education Review, 39(1), 28-53.

Arnove, R. F. (1995b). Adult education and state policy in Latin America: the contrasting cases of Mexico and Nicaragua. Comparative Education, 31(3), 311-326.

Azuaje, P. P. (2010). Madre armada y niño. Representación de la mujer nueva en los murales de la Revolución Sandinista en Nicaragua. Apuntes. Revista de Estudios sobre Patrimonio Cultural, 23(1), 8-19.

Baracco, L. (2004). The Nicaraguan literacy crusade revisited: The teaching of literacy as a Nationbuilding project. Bulletin of Latin American Research, 23(3), 339-354.doi.org/10.1111/j.02613050.2004.00112.x

Bataillon, G., ve Juárez, V. G. (2013). Los "muchachos" en la revolución sandinista (Nicaragua, 19781980). Estudios Sociológicos, 31(92), 303-343.

Bender-Slack, D. (2018). ¡Puño en Alto! The Nicaraguan Literacy Campaign and what it means for literacy today. Educational Studies, 54(3), 271-284. https://doi.org/10.1080/00131946.2017.1411262

Bender-Slack, D. A. (2020). The Nicaraguan Literacy Campaign: the power and politics of literacy. The United States: Lexington Books.

Bloch, T., ve Acevedo, A. (1988). Library education in revolutionary Nicaragua. Journal of Education for Library and Information Science, 28(3), 169-176.

Booth, J. A. (2019). The end and the beginning: the Nicaraguan Revolution, revised and updated. The United Kingdom: Routledge.

Cardenal, F., ve Miller, V. (1982). Nicaragua: Literacy and revolution. Prospects, 12(2), 201-212.

Cardenal Martínez, S. J. (1980). Fernando Cardenal habla de la Cruzada Nacional de Alfabetización. Encuentro: Revista Académica de la Universidad Centoamericana, (16), 15-16.

Catter, T. V. (2011). Intercultural bilingual education in Nicaragua: Contextualisation for improving the quality of education. International Review of Education, 57(5-6), 721-735.

Collins, S. (1987). Education in Nicaragua: what difference can a revolution make?. Social Policy, 18(2), 47-53.

Coraggio, J. L. (1984). Revolución y democracia en Nicaragua. Encuentro: Revista Académica de la Universidad Centroamericana, (21), 5-31. 
1980 Nikaragua Okuryazarlık Kampanyası'ndaki Propaganda Posterlerinin Kitap Okuma Boyutunda İncelenmesi

An Examination of the propaganda Posters in the 1980 Nicaragua Literacy Campaing in the Context Of

Reading Books

Cordero, G., ve Monge, C. (1981). La cruzada nacional de alfabetización en Nicaragua. Revista Educación, 71-86.

Cuzán, A. G., ve Heggen, R. J. (1982). A micro-political explanation of the 1979 Nicaraguan Revolution. Latin American Research Review, 17(2), 156-170.

Cuzán, A. G. (1990). Resource mobilization and political opportunity in the Nicaraguan Revolution: the Theory. American Journal of Economics and Sociology, 49(4), 401-412.

Çakı, C., Zorlu, Y. ve Karaca, M. (2017). Türk sinemasında Nazizm ideolojisi: "Kırımlı" filmi ve göstergebilimsel analizi, Sosyoloji Konferansları, (56), 67-95. doi: 10.18368/iusoskon.328523

Çakı, C., Gazi, M. A., Çakı, G., ve Gülada, O. (2020). Likbez kampanyası dönemindeki propaganda posterleri üzerine göstergebilimsel bir inceleme. Türk Kütüphaneciliği, 34(4), 663-692. Doi: $10.24146 /$ tk. 806892

De Diego Romero, J. (2003). Revolución y legitimidad política en América Latina contemporánea: Los casos de Cuba y Nicaragua. Revista Complutense de Historia de América, (29), 151-178.

Deiner, J. T. (1981). The Nicaraguan literacy crusade. Journal of Reading, 25(2), 118-125.

De La Pena, S. (1980). Nicaragua: una revolución andando. Investigación Económica, 39(154), 89-92.

Downs, C., ve Kusnetzoff, F. (1982). The changing role of local government in the Nicaraguan Revolution. International Journal of Urban and Regional Research, 6(4), 533-548.

Erol, E. G. (2020). Nazi Almanya'sında yayıncılık, Nazizm ideolojisinin yaydığı anti-semitist söylemlerin inşası ve kitapların propaganda amaçlı kullanımı. Türk Kütüphaneciliği, 34(4), 693722. doi: $10.24146 /$ tk. 818460

Fernandez, X. B. P. (1985). Alfabetización y educación de adultos en Nicaragua. Educar, 131-146.

Fisher, S. (1986). The Nicaraguan Revolution and the US response: Lessons for Appalachia. Appalachian Journal, 14(1), 22-37.

Flora, J. L., McFadden, J., ve Warner, R. (1983). The growth of class struggle: The impact of the Nicaraguan literacy crusade on the political consciousness of young literacy workers. Latin American Perspectives, 10(1), 45-61.

Frost, L. (1995). The bilingual education of indigenous children in Nicaragua under the 1987 Autonomy Statute: The effective limits of legal change. The International Journal of Children's Rights, 3(1), 51-68.

Garfield, R. M., ve Vermund, S. H. (1986). Health education and community participation in mass drug administration for malaria in Nicaragua. Social Science \& Medicine, 22(8), 869-877.

Gariazzo, A. (1991). La revolución no da la solución. La mujer en la Nicaragua sandinista. Nueva Sociedad, (113), 51-58.

Gazi, M. A., Çakı, C., Gülada, M. O., ve Çakı, G. (2020). Çin Halk Cumhuriyeti kültür devrimi sürecinde okuma alışkanlığının propaganda posterlerinde sunumu. Türk Kütüphaneciliği, 34(3), 406-431. doi: 10.24146/tk.778685

Gülada, M. O. (2019). Çocuk işçiliğinin önlenmesine yönelik hazırlanan kamu spotu reklamlarının göstergebilimsel analizi. SGD-Sosyal Güvenlik Dergisi, 9(1), 215-235. doi: $10.32331 / \mathrm{sgd} .582761$

Geale, K. (2010). The effects of mothers' education on the nutritional outcomes of their children in Nicaragua. SURG Journal, 3(2), 23-30. Doi:10.21083/SURG.V3I2.1094

Gershberg, A. I. (1999). Education 'decentralization' processes in Mexico and Nicaragua: legislative versus ministry-led reform strategies. Comparative Education, 35(1), 63-80. 
González Arana, R. (2010). Nicaragua. Dictadura y revolución. Memorias, 1(10), 231-264.

Gordon, D. R., ve Munro, M. M. (1983). The external dimension of civil insurrection: International organizations and the Nicaraguan revolution. Journal of Interamerican Studies and World Affairs, 25(1), 59-81.

Gordon, E. T. (1985). Etnicidad, conciencia y revolución: La cuestión Miskito-Creole en Nicaragua. Encuentro: Revista Académica de la Universidad Centroamericana, (24-25), 117-138.

Gorman, S. M. (1981). Power and consolidation in the Nicaraguan Revolution. Journal of Latin American Studies, 13(1), 133-149.

Guerrero, M. R. (2014). El proceso de institucionalización del poder en Nicaragua: De la revolución sandinista a la Constitución política de 1987. Revista de Estudios Políticos, (163), 157-187.

Guiraud, P. (2016) Göstergebilim. M. Yalçın. (Çev.). 3. Baskı. Ankara: İmge Kitabevi.

Gurdián, G., ve Salamanca, D. (1990). Bilingual education in Nicaragua. Prospects, 20(3), 357-364.

Gülada, M. O. (2019). 1936 Berlin Olimpiyatları'nda spor yayıncılığının propaganda amaçlı kullanımı: Olympia filmi üzerine inceleme. TRT Akademi, 4(8), 326-344.

Handa, S., Pineda, H., Esquivel, Y., Lopez, B., Gurdian, N. V., ve Regalia, F. (2009). Non-formal basic education as a development priority: Evidence from Nicaragua. Economics of Education Review, 28(4), 512-522.

Hanemann, U. (2006). Nicaragua's literacy campaign. Paper Commissioned for the EFA Global Monitoring Report, 1-13.

Hernández, G. E., Moncada, G., del Carmen Robles, O., López, S. L., ve Terán, L. A. (2008). Reporte sobre el estado actual de la educación de personas jóvenes y adultas en México, Honduras, Nicaragua, El Salvador y Panamá. Revista Interamericana de Educación de Adultos, 30(2), 739.

Hodges, D. C. (1986). Intellectual foundations of the Nicaraguan revolution. The United States: University of Texas Press.

IISG (2021a). Zincir konulu propaganda posteri. Erişim adresi https://search.iisg.amsterdam/Record/1135718

IISG (2021b). Özgürlük konulu propaganda posteri. Erişim adresi https://search.iisg.amsterdam/Record/1135734

IISG (2021c). Kitleler konulu propaganda posteri. Erişim adresi https://search.iisg.amsterdam/Record/1135737

IISG (2021d). Yumruk konulu propaganda posteri. Erişim adresi https://search.iisg.amsterdam/Record/1135749

IISG (2021e). Destek konulu propaganda posteri. Erişim adresi https://search.iisg.amsterdam/Record/1135753

IISG (2021f). Savaş konulu propaganda posteri. Erişim adresi https://search.iisg.amsterdam/Record/1135774

IISG (2021g). Okuryazar konulu propaganda posteri. Erişim adresi https://search.iisg.amsterdam/Record/1135780

IISG (2021h). Kadın konulu propaganda posteri. Erişim adresi https://search.iisg.amsterdam/Record/1177433

IISG (2021i). Görev konulu propaganda posteri. Erişim adresi https://search.iisg.amsterdam/Record/939498

Jameson, F. (1987). Tomás Borge on the Nicaraguan Revolution. New Left Review, 164, 53-64. 
1980 Nikaragua Okuryazarlık Kampanyası'ndaki Propaganda Posterlerinin Kitap Okuma Boyutunda İncelenmesi

Jamison, D. T., Searle, B., Galda, K., ve Heyneman, S. P. (1981). Improving elementary mathematics education in Nicaragua: An experimental study of the impact of textbooks and radio on achievement. Journal of Educational Psychology, 73(4), 556-567.

Jiménez, I. M. (1998). La alfabetización popular en El Salvador, Nicaragua y Costa Rica: niveles, tendencias y desfases (1885-1950). Fuentes, 143, 377-393.

Kleinbach, R. (1985). Nicaraguan literacy campaign: its democratic essence. Monthly Review, 37, 7585.

Kroeger, A., Meyer, R., Mancheno, M., ve González, M. (1996). Health education for community-based malaria control: An intervention study in Ecuador, Colombia and Nicaragua. Tropical Medicine \& International Health, 1(6), 836-846.

Krujit, D. (2011). Revolución y contrarrevolución: el gobierno sandinista y la guerra de la Contra en Nicaragua, 1980-1990. Desafios, 23(2), 53-82.

Lankshear, C. (1986). Dawn of the people: The right to literacy in Nicaragua. The Australian Journal of Education Studies, 7(1), 31-45.

Lankshear, C., Sandiford, P., Montenegro, M. M., Sanchez, G., Coldham, C., ve Cassel, J. (1995). Twelve Years On: Women's literacy in a Nicaraguan municipality. International Journal of Lifelong Education, 14(2), 162-171.

MacAdam, C. (1984). Towards democracy: The literacy crusade in Nicaragua. International Review of Education, 30(3), 359-368.

Marini, R. M. (1981). The Nicaraguan Revolution and the Central American Revolutionary Process. Contemporary Marxism, (3), 62-66.

Martinez-Rugama, G. I., Rivas, J. A., ve Martinez-Andrades, E. (2017). La educación en Nicaragua. Revista Iberoamericana de Bioeconomia y Cambio Climático, 3(5), 711-733. https://doi.org/10.5377/ribcc.v3i5.5944

Martínez, J. J. F.,\& Arrechavala, J. R. (2020). Globalización y Educación en Nicaragua, impacto en el sistema educativo y transformación de las culturas escolares. Revista Compromiso Social, (3), 45-50.

Miller, V. (2019). Between struggle and hope: The Nicaraguan literacy crusade. The United Kingdom: Routledge.

Miron, G. (1995). The development and current status of special education in Nicaragua. Prospects, 25(2), 229-243.

Molyneux, M. (1984). Movilización sin emancipación? Los intereses de la mujer, Estado y revolución en Nicarágua. Revista Desarrollo y Sociedad, (13), 179-195.

Mora, F. (2013). Cinco años de Educación Indígena en Nicaragua. CUHSO Cultura-Hombre-Sociedad, (1), 259-272.

Mosinger, E. S. (2019). Balance of Loyalties: Explaining Rebel Factional Struggles in the Nicaraguan Revolution. Security Studies, 28(5), 935-975. https://doi.org/10.1080/09636412.2019.1662481

Müller, T. R. (2007). Education and gender in revolutionary societies: Insights from Vietnam, Nicaragua, and Eritrea. Compare, 37(5), 635-650. https://doi.org/10.1080/03057920701420908

Nolff, M. (1982). La vía crucis de la revolución sandinista. Nueva Sociedad, 63, 33-46.

Ortega, M. (1989). Notas sobre la democracia y la revolución en Nicaragua. Realidad: Revista de Ciencias Sociales y Humanidades, (10), 397-409. 
Palazón Sáez, G. D. (2008). Polémicas culturales, compromiso intelectual y revolución en Nicaragua. L'Ordinaire des Amériques, (211), 9-30.https://doi.org/10.4000/orda.2534

Parra, S. (2008). Nicaragua: ¿la alfabetización todavía es revolución?. Diálogos: Educación y Formación de Personas Adultas, 1(53), 43-52.

Peña, R., Liljestrand, J., Zelaya, E., ve Persson, L. A. (1999). Fertility and infant mortality trends in Nicaragua 1964-1993. The role of women's education. Journal of Epidemiology \& Community Health, 53(3), 132-137. doi: 10.1136/jech.53.3.132

Peña, R., Wall, S., ve Persson, L. A. (2000). The effect of poverty, social inequity, and maternal education on infant mortality in Nicaragua, 1988-1993. American Journal of Public Health, 90(1), 64-69. doi: 10.2105/ajph.90.1.64

Pérez, R. S. (2002). La Revolución Sandinista en Nicaragua. Revista de la Universidad de México, (617), 13-21.

Perla, H. (2009). Heirs of Sandino: The Nicaraguan revolution and the US-Nicaragua solidarity movement. Latin American Perspectives, 36(6), https://doi.org/10.1177/0094582X09350765

Polvorosa, J. C. (2002). Retos del sistema educativo nicaragüense. Encuentro, (63), 94-103.

Prevost, G. (1996). The Nicaraguan revolution-six years after the Sandinista electoral defeat. Third World Quarterly, 17(2), 307-328.

Quintanilla, R. (1993). A suspended dialogue: The Nicaraguan revolution and the visual arts. Third Text, $7(24), 25-34$.

Robles, L. G., ve Lucio-Villegas, E. (2014). Alfabetización, oralidad y participación. Reflexiones sobre una experiencia en Nicaragua. Cuestiones Pedagógicas. Revista de Ciencias de la Educación, (23), 65-84.

Rocha, J. L. (2003). La década de los años 80: Revolución en Nicaragua, revolución en la caficultura nicaragüense. Anuario de Estudios Centroamericanos, 29(1-2), 69-99.

Rodríguez, M. V. R. (1990). Nicaragua, una campaña de alfabetización. Cuadernos de Pedagogía, (179), 30-33.

Rooper, A., ve Smith, H. (1986). From nationalism to autonomy: The ethnic question in the Nicaraguan revolution. Race \& Class, 27(4), 1-20.

Ryan, P. (2000). Structure, agency, and the Nicaraguan Revolution. Theory and Society, 29(2), 187-213. https://doi.org/10.1023/A:1007015218826

Sáez, G. D. P. (2007). Antes, durante, después de la revolución... la lucha continúa: Movimiento feminista en Nicaragua. Lectora: Revista de Dones i Textualitat, (13), 115-132.

Sandiford, P., Lankshear, C., Montenegro, M. M., Sánchez, G., ve Cassel, J. (1994). The Nicaraguan Literacy Crusade - How lasting were its benefits?. Development in Practice, 4(1), 35-49. https://doi.org/10.1080/096145249100077481

Schaefer-Rodriguez, C. (1985). Peace, poetry, and popular culture: Ernesto Cardenal and the Nicaraguan revolution. Latin American Literary Review, 13(26), 7-18.

Serra Vázquez, L. H. (1985). Democracia y revolución en Nicaragua. Encuentro: Revista Académica de la Universidad Centroamericana, (23), 70-78.

Shier, H., Padilla, M. L., Molina, N., Barrera, L., Molina, M., Castillo, Z., ve Ortiz, K. (2013). Claiming the right to quality education in Nicaragua. Children's Rights and Education: International Perspectives, 188-202.

Siebert, R. J. (1980). Ernesto Cardenal and the Nicaraguan revolution: From theological theory to revolutionary praxis. CrossCurrents, 30(3), 241-251. 
Smith, C. (2008). Revolutionaries and revivalists: Pentecostal eschatology, politics and the Nicaraguan revolution. Pneuma, 30(1), 55-82.

Steppe, J. D., Blake, B. J., Dyal, M. A., Bailey, T. S., Porter, K. J., ve Thompson, J. (2020). Conducting a health education needs assessment in rural Nicaragua. Health Education Journal, 79(5), 556568. https://doi.org/10.1177/0017896919896615

Terradellas, M. R., ve Parra, S. (2008). La Red universitaria yo, sí puedo: una buena práctica de cooperación universitaria con la alfabetización de Nicaragua. Diálogos: Educación y Formación de Personas Adultas, 1(53), 35-41.

Torres, R. M. (1980). Nicaragua: Revolución y alfabetización. Nueva Antropología, 4(16), 155-176.

Torres, C. A. (1991). The state, nonformal education, and socialism in Cuba, Nicaragua, and Grenada. Comparative Education Review, 35(1), 110-130.

Tünnermann Bernheim, C. (1980). Cruzada Nacional de Alfabetización. Prioridad de la Revolución. Encuentro: Revista Académica de la Universidad Centroamericana, (16), 9-14.

Vannini, M. (2007). El Tren Cultural y el rescate de la memoria de la Cruzada Nacional de Alfabetización. Transatlántica de Educación, (2), 116-124.

Vargas, O. R. (1998). Nicaragua. Revolución, restauración y futuro. Nueva Sociedad, 155, 15-22.

Vilas, C. M. (1990). Nicaragua: El camino de la derrota electoral y el porvenir de la Revolución Sandinista. Realidad: Revista de Ciencias Sociales y Humanidades, (14), 135-164.

Wright, B. E. (1990). Pluralism and Vanguardism in the Nicaraguan Revolution. Latin American Perspectives, 17(3), 38-54.

Zimmermann, M. (2001). Sandinista: Carlos Fonseca and the Nicaraguan Revolution. The United States: Duke University Press. 